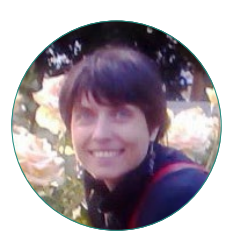

Т. Л. Кукса

\title{
ДОУЛЬСКОЕ СОПРОВОЖДЕНИЕ РОДОВ: \\ ГЕНЕЗИС, ДИСКУРСЫ И ПРАКТИКИ ЭМОЦИОНАЛЬНОЙ И ФИЗИЧЕСКОЙ НЕМЕДИЦИНСКОЙ ЗАБОТЫ
}

\section{Правильная ссылка на статью:}

Кукса Т. Л. Доульское сопровождение родов: генезис, дискурсы и практики эмоциональной и физической немедицинской заботы // Мониторинг общественного мнения: экономические и социальные перемены. 2021. № 3. С. 226-249. https://doi.org/10.14515/ monitoring.2021.3.1902.

\section{For citation:}

Kuksa T. L. (2021) Doula Support During Childbirth: Genesis, Discourses, and Practices of Emotional and Physical Non-Medical Care. Monitoring of Public Opinion: Economic and Social Changes. No. 3. P. 226-249. https://doi.org/10.14515/monitoring.2021.3.1902. (In Russ.) 
ДОУЛЬСКОЕ СОПРОВОЖДЕНИЕ РОДОВ: ГЕНЕЗИС, ДИСКУРСЫ И ПРАКТИКИ ЭМОЦИОНАЛЬНОЙ И ФИЗИЧЕСКОЙ НЕМЕДИЦИНСКОЙ ЗАБОТЫ

КУКСА Татьяна Леонидовна - начальник отдела реформирования законодательства Института государственного и муниципального управления, Национальный исследовательский университет “Высшая школа экономики", Москва, Россия; аспирантка Центра медицинской антропологии, Институт этнологии и антропологии Российской академии наук имени Н. Н. Миклухо-Маклая, Москва, Россия

E-MAIL: tutosha@gmail.com https://orcid.org/0000-0002-8696-7284

Аннотация. В фокусе статьи находятся практики эмоциональной, информационной и физической возмездной помощи женщинам во время беременности, в родах и послеродовый период, а также их русскоговорящие поставщики независимые от родовспомогательных учреждений перинатальные эксперты, самопредъявляющие себя преимущественно как "профессиональные", "родовые" или "послеродовые" доулы. С помощью неовеберианского подхода к (пара)медицинским знаниям, занятостям и профессиям в статье проиллюстрировано государственное и рыночное влияние на распространение немедицинских практик эмоциональной и физической заботы в современном российском роддоме.

Несмотря на неформальный статус немедицинских помощниц и связанные с ним риски, образовательный и цифровой активизм доульской сети приводит не только к конструированию специальной компетенции, стандартов,
DOULA SUPPORT DURING CHILDBIRTH: GENESIS, DISCOURSES, AND PRACTICES OF EMOTIONAL AND PHYSICAL NON-MEDICAL CARE

Tatiana L. KUKSA ${ }^{1,2}$ - Head of the Legislation Reform Department at Institute for Public Administration and Governance; PhD student at Center of Medical Anthropology

E-MAIL: tutosha@gmail.com https://orcid.org/0000-0002-8696-7284

\footnotetext{
1 HSE University, Moscow, Russia

2 Institute of Ethnology and Anthropology of the Russian Academy of Sciences, Moscow, Russia
}

Abstract. The article regards the practice of paid emotional, informational and physical assistance to women during pregnancy, childbirth and the postpartum period, as well as the Russian-speaking providers of these services: perinatal experts independent of obstetric institutions, self-presenting themselves mainly as "professional", "partum", or "postpartum" doulas. Using a neo-Weberian approach to (para)medical knowledge, jobs, and professions, the author illustrates influence of the state and market on the spread of non-medical emotional and physical care practices in the modern Russian maternity hospital.

Despite the informal status of non-medical assistants and the associated risks, the educational and digital activism of the doula network leads to the construction of special competence, standards, ethics, and language, but also to an increase in the number of "certified" doulas. Labor and educational mobility, family and digital everyday life of care 
этики и языка, но также к росту количества "сертифицированных" доул. Трудовая и образовательная мобильность, семейная и цифровая повседневность нестатусных агентов заботы, вовлекающихся в прекарную и возмездную материнскую самозанятость, содействуют автономному саморегулированию сообщества, рецепции и стандартизации подходов, пересборке границ деятельности, точечному волонтерству и популяризации доульского дискурса.

Описанные в статье явления способствуют ускоренному изменению всего медицинского ландшафта, биомедицинских знаний и дискурса в сторону дальнейшей гуманизации родовспоможения (преимущественно коммерческого) - пациентоориентированной коммуникации, информированного согласования медицинских вмешательств, частичной демедикализации, учета данных доказательной медицины в новых протоколах и рутинных практиках, расширения агентности рожениц при выборе участников, места и способа родов. Исследование основано на коммуникативном анализе дискурсов и нарративов, которые были собраны с 2017 по 2021 г. в ходе полевой этнографии перинатальных практик и их репрезентаций в различных контекстах и источниках (полуструктурированные глубинные интервью, социальные сети, нормативно-правовые акты, медиаресурсы).

Ключевые слова: доула, забота, прекарная занятость, негативная реципрокность, самозанятость, материнский фриланс, экспертные знания, партнерские роды, контрактные роды, сопровождение родов, рынки родовспоможения, государственное регулирование agents with no official status involved in precarious and paid maternal self-employment also contribute to autonomous self-regulation of the community, reception and standardization of approaches, reassembling the boundaries of activity, local volunteering and popularization/ broadcasting of doula discourse.

The phenomena described in the article contribute to an accelerated change in the entire medical landscape, biomedical knowledge and discourse towards further humanization (mainly commercial) of modern obstetrics. In particular, the author records the emergence of patient-centered communication, informed coordination of medical interventions, partial demedicalization, taking into account evidence-based medicine data in new protocols and routine practices, expanding the agency of women in labor when choosing participants, place, and method of delivery.

The research is based on a communicative analysis of discourses and narratives that have been collected since 2017 in the field ethnographic study of perinatal practices and their representations in various contexts and sources. The database includes semi-structured indepth interviews, information from social networks and media resources, and regulations.

Keywords: doula, care, precarious employment, negative reciprocity, self-employment, maternal freelance, expert knowledge, partner childbirth, contract childbirth, obstetric markets, government regulation, childbirth support 


\section{Введение: профессиональные и альтернативные агенты заботы в родах как объект исследовательского интереса}

Высококвалифицированная и статусная деятельность врачей выступает традиционным объектом академического интереса англосаксонских, континентальных и российских исследователей профессий, принадлежащих разным теоретическим дисциплинам и подходам [Freidson, 1986, 1988, 2001; Saks, 1994, 1995, 1998, 2003, 2010, 2012; Rouhier-Willoughby, 2008; Абрамов, 2013, 2016, 2018; Сакс, Олсоп, 2003; Щепанская, 2010].

В России предусмотрен единственный легальный и периодически обновляемый порядок оказания медицинской помощи в период родов, которая реализуется в общем случае на территории лицензированных медицинских организаций с участием аккредитованных специалистов - врачей разных специальностей и среднего специального персонала здравоохранения (акушерок и медицинских сестер) ${ }^{1}$. По итогам анализа нормативно-правовых актов ${ }^{2}$, данных полевого интервьюирования и мониторинга правоприменительной практики оказывается, что российские доктора, работающие в родовспомогательном секторе акушерыгинекологи, анестезиологи-реаниматологи и неонатологи, имеют:

- исключительное монопольное положение на рынке медицинских услуг в сфере родовспоможения, поддерживаемое всей системой государственного регулирования здравоохранения;

- эксклюзивную компетенцию, ограниченную специализацией, подтвержденную документами о высшем образовании и квалификации;

- легитимные, монополизированные биомедицинские знания в статусе научных (со сложной переводимостью на обыденный язык для коммуникации с пациентом) и устойчивую систему их передачи;

- усложненный допуск к осуществлению деятельности и периодическую аккредитацию для подтверждения квалификации и соответствия специализации;

- особенный правовой статус и высокий уровень ответственности;

- жестко регламентированную автономию принятия медицинских и юридически значимых решений при взаимодействии с пациентом;

- условную (в контексте российского государства) коллективную автономию от государства в случаях локального добровольного и обязательного саморегулирования, которое де-факто чаще всего проявляется как точечная солидарность при неформальных взаимодействиях и в случаях уголовных преследований [Кукса, 2020a], а также при разработке клинических рекомендаций.

Вместе с тем в крупных российских городах на рынке перинатальных услуг наряду со сверхзарегулированными, ригидными и одновременно эксклюзивными профессионалами-медиками (professional agents of care) работают менее статусные специалисты дородового, послеродового ухода и сопровождения женщин в родах, так называемые немедицинские агенты заботы (popular and folk agents of care) [Freidson, 1988; Kleinman, 1978].

Англосаксонские и российские исследовательницы родовспоможения рассматривают альтернативных поставщиков чаще всего в качестве полноправных

1 Ф3 № 323 от 22.11.2011; приказ Минздрава России от 20.10.2020 № 1130н.

2 Ф3 № 323 от 22.11.2011; приказы Минздрава России от 02.06.2016 № 334н и от 20.10.2020 № $1130 \mathrm{H}$. 
и самостоятельных акторов феминистских проектов и активистских движений, конкурирующих с монополистами-медиками за "авторитетные знания" о родах и за контроль над женской репродукцией и деторождением [Arney, 1982; Arney, Neill, 2008; Belousova, 2012; Jordan, 1997; Davis-Floyd, Davis, 1996; Davis-Floyd, Sargent, 1997; Бороздина, 2014, 2016; Денисова, 2019]. Хотя траектории трудовой и семейной мобильности нестатусных агентов заботы затрагиваются в представленных работах, но чаще всего это делается с использованием теоретического ресурса гендерной социологии и в меньшей степени - социологии знаний, профессий и занятости, кроме отдельных исследований [Бороздина, 2014, 2016; Денисова, 2019]. Трудовая и образовательная мобильность, семейная повседневность и зависимость российских альтернативных специалистов, не принадлежащих медицинской системе, от рыночных и бюрократических факторов и контекстов ускользает из внимания социальных исследователей (не)медицинских занятостей, в том числе в силу сложности включенного наблюдения за самими практиками перинатальной помощи и неформальными взаимодействиями на территории закрытых учреждений или на дому. Между тем мои этнографические наблюдения показывают, что трудовая деятельность и материнская повседневность (не)медицинских агентов заботы в сфере родовспоможения имеют разную степень автономности от властных субъектов и зависимости от правового регулирования сферы родовспоможения [Кукса, 2018, 2019, 2020a, 2020b]. В целом уровень признания (легитимности) индивидуальных акушерок и доул разнится как со стороны медицинских организаций (администрация, врачи и рядовой персонал), так и общества (медиа, сети, клиенты, конкуренты, семья).

Коль скоро в системе родовспоможения государственный регулятор и законодатель поддерживает монопольное положение медицинских организаций и врачей, для изучения (пара)медицинских знаний, занятостей и профессий в бюрократических и рыночных контекстах лучше всего подходит, на мой взгляд, неовеберианская перспектива (в изводе прежде всего британского социолога Майка Сакса) [Saks, 2012]. Опираясь на нее, я привожу этнографические факты и контексты государственного и рыночного влияния как на распространение немедицинских практик эмоциональной и физической заботы доул в роддоме, так и на попытку монополизации (олигополии) активностей посредством автономного саморегулирования, точечного волонтерства, рецепции и пересборки (подгонки) подходов, конструирования и трансляции доульских компетенций, специальных навыков и дискурса. При этом я не рассматриваю роды как пространство для борьбы (полу)профессиональных групп за власть и контроль за женскими репродуктивными опытами. Я анализирую практики немедицинской заботы с помощью ресурсов интерпретативной/символической антропологии [Geertz, 1973, 1983] и теории коммуникации [Бахтин, 1979]. Данный "понимающий", "эмический" подход не предполагает “концептуальной манипуляции с обнаруженными фактами, логической реконструкции обыденной реальности" или "открытия Континента Смысла и картографирования его безжизненного ландшафта" [Geertz, 1973: 20]. В фокусе моего исследования находятся аутентичные репрезентации и интерпретации доул, авторские интенции, коммуникативный и бюрократический контекст 
взаимодействий, несводимые исключительно к гендерному "символическому универсуму", а также борьбе за статус, экспертизу и знания.

Сбор материала осуществлялся в период с 2017 г. по 2021 г. в ходе полевой этнографии перинатальных практик и их репрезентаций в различных контекстах и источниках (полуструктурированные глубинные интервью, социальные сети, нормативно-правовые акты, медиаресурсы). Я опираюсь также на личный опыт включенного наблюдения изучаемых сообществ и практик десятилетней давности, полученный в период собственной беременности и родов. В основу настоящей статьи легли данные из актуальных и утративших силу нормативно-правовых и распорядительных актов, сетевых пабликов, доульских конференций, лекций, тренингов и полуструктурированных интервью с перинатальными специалистами, проживающими в Москве, Московской области и Санкт-Петербурге.

В первом параграфе статьи я показываю генезис и факторы, заложившие основы для новой доульской занятости и немедицинской заботы, такие как формирование легального рынка и агентов индивидуальной акушерской поддержки на территории роддома, инфраструктурные и законодательные улучшения системы родовспоможения. Во втором параграфе приведена характеристика доульского дискурса в условиях конкуренции агентов заботы, а также дискурсивные особенности обоснования специальной немедицинской компетенции, артикуляции границ, стандартов заботы и этики. В третьем параграфе я описываю фактические активности доул: нерегулируемый образовательный и просвещенческий бизнес, попытки саморегулирования, унификации практик, а также проблемы сопровождений в роддоме и их оплаты (которые я именую как негативная реципрокность). В заключительном параграфе изложены выводы.

\section{Факторы появления рынка и агентов немедицинской заботы в родах: независимое акушерство, отдельные родильные боксы и партнерские роды}

Российский рынок консультационных, образовательных, психологических и (пара)медицинских услуг, востребованных семьями в перинатальный и постнатальный период, крайне разнообразен и относится преимущественно к женскому самозанятому и/или неформальному сектору экономики с минимальным государственным регулированием процессов и участников.

Первопроходцами, освоившими различные формы дородового и послеродового ухода, а также поддержку в родах, были адепты идеологии "естественного" и "водного" деторождения [Belousova, 2012; Бороздина, 2014, 2016; Кукса, 2018, 2019]. Локальные инициативы московских специалистов изначально ограничивались взаимным обучением и самопомощью в домашних родах. Однако увлечение темой (и желание помогать женщинам) приводило их в медицинские училища, где они получали дополнительную специализацию - фельдшерское или акушерское образование. Реже происходили обратные ситуации, когда, например, роддомовские акушерки в Санкт-Петербурге уходили из системы, чтобы оказывать индивидуальную помощь [Бороздина, 2014]. Оставаясь сторонниками легализации индивидуального акушерского сопровождения нормальных (физиологических) родов на дому (по аналогии с рядом европейских стран), работающие в Центре 
традиционного акушерства (далее - ЦТА) специалисты с 2006 г. получили возможность легально сотрудничать с московскими роддомами в рамках платных контрактов по разработанной Центром программе “мягких родов" [Кукса, 2018].

С момента реализации первого независимого от бюджетной системы профессионального акушерского проекта ЦТА и легитимации (восходящей мобильности) аккредитованных альтернативных специалистов период антимедикализирующего диссидентства и теневого рынка домашних родов 1990-х и начала 2000-х годов постепенно перешел в фазу коммерчески выгодного взаимодействия и взаимопроникновения биомедицинских и альтернативных подходов [Кукса, 2018]. Аналогичный британский кейс про травников и иглотерапевтов изложен Майком Саксом: первые получили правительственное регулирование (в отличие от вторых) по причине опасных последствий от деятельности в отсутствие государственного признания комплементарной практики [Saks, 2012].

Сегодня аккредитованные акушерки нескольких конкурирующих московских частных медицинских центров, оформленные в штат роддома на часть тарифной ставки, легально оказывают возмездную индивидуальную поддержку рожениц в изолированном родовом боксе (который оплачивается дополнительно по отдельному платному контракту вместе с выбранным врачом или с дежурной бригадой). Они имеют право осуществлять все нормативно прописанные акушерские функции, несут за них ответственность, выполняют назначения врача роддома, а потому предпочитают сотрудничать с конкретными акушерами-гинекологами и роддомами, проводящими принципы гуманного родовспоможения и поддерживающими программы "мягких" родов. Однако стоимость двух платных контрактов (с роддомом и медицинским акушерским центром) существенно ограничивает доступность и, следовательно, емкость легального рынка родовспоможения с индивидуальной поддержкой опытной акушерки.

[Как независимые акушерки мимикрируют под доул? Насколько это распространено? Примерные цифры?] ${ }^{3}$ Сейчас независимым акушеркам, не работающим в центрах типа ЦТА или Акушерство.клаб (у центров есть лицензия на мед. деятельность и официальные договоры с роддомами), нет нужды мимикрировать: они оформляются на кусочки ставки во все интересующие их роддома и таким образом имеют право работать как акушерки в роддоме. Прямо роды принимать. Роддомам это выгодно: чтобы купить контракт с такой акушеркой, необходимо купить контракт с самим роддомом. Мимо роддома нельзя. То есть 100-150 <тысяч рублей> роддому + 50-60 <тысяч рублей> за акушерку. Это вам не с доулой по ОМС пойти. (Доула, юрист, трое детей, 15.01.2020)

Идеологи “мягкого" (“естественного", «водного", "домашнего») деторождения и представители независимого акушерства заложили предпосылки для интенсивного распространения немедицинских эмоциональных и физических практик и их поставщиков (агентов заботы) вне медицинской организации. Однако самостоятельные образовательные и волонтерские проекты, а также попытки автономизации и стандартизации немедицинских практик заботы внутри меди-

\footnotetext{
з Здесь и далее в цитатах в квадратных скобках приводятся вопрос(ы) исследователя информанту.
} 
цинских учреждений появились значительно позднее (фрагментарно - с 2011 г., системно - с 2015 г.) благодаря инфраструктурным и законодательным изменениям системы родовспоможения в 2011 г.

Федеральный закон № 323 от 22.11.2011 закрепляет за женщиной право присутствия мужа в родах без взимания платы (или выбора семейно-ориентированных или партнерских родов с ее согласия) при наличии определенных условий (например, отдельного бокса, отсутствия инфекционных заболеваний у партнера, которые в условиях пандемии подтверждаются в том числе отрицательным мазком на COVID-2019) ${ }^{4}$. Конкуренция медицинских учреждений не только за платных, но и за бюджетных клиентов, появление (ремонт) отдельных родильных боксов, открытость к альтернативным специалистам и практикам главных врачей роддомов и некоторые другие факторы постепенно способствовали не только контрактному, но даже неформальному допуску на закрытую территорию роддома новых сопровождающих роженицу лиц, не имеющих ни родственных связей, ни медицинской/ акушерской квалификации. Так, с 2015 г. на территорию известного и популярного в акушерских и затем доульских кругах московского роддома № 68 благодаря прооденовской позиции главного врача стали допускать не только мужа, мать или сестру роженицы, но также не имеющих с ней родства подруг и главное - доул, даже в рамках обязательного медицинского страхования (далее-ОМС). В конце 2018 г. роддом закрыли на реконструкцию.

Просто так получилось, что 68-й, он уже был не просто роддом, а именно стал каким-то социальным таким проектом в Москве - самым лояльным роддомом к женщинам, где можно было и за дорого родить, и за недорого, и по ОМС. Можно было прийти с доулой, например. <...> И партнерские роды могли там быть бесплатные - и с папой, и с доулой можно было прийти. Будет ли сейчас это там сохраняться, не знаю. Конечно, во многом это на этом человеке держалось - на Вученович Юлии Дмитриевне. <...> Была ли это ее задача или нет, но так или иначе, я не знаю, мне кажется, она сделала очень хороший социальный проект. В одном из самых дорогих роддомов города Москвы, конечно, обидно, что до сих пор за крутые деньги не было там возможности рожать гуманно - получить именно то, что женщина хочет. Но, может быть, сейчас туда придут специалисты и такая возможность будет у всех женщин, кто платит много денег, в том числе. (Доула, психолог, трое детей, 12.02.2018, 17.02.2018)

В роддомах доулы выступают в качестве квазипартнера, представляясь родственницей пациентки, если медицинское учреждение не проводит документальную проверку этого факта и не взимает платы. По данным интервьюирования (к началу пандемии ${ }^{5}$ ), только три-четыре московских роддома де-факто разрешали присутствие доул во время родов в качестве поддерживающих партнеров по программе ОМС, то есть без необходимости заключения роженицей платного контракта с роддомом.

\footnotetext{
4 ФЗ № 323 от 22.11.2011; Письмо Минздрава России от 06.05.2014 N15-4/10/2-3185; приказ Минздрава России от 20.10.2020 № 1130н; Методические рекомендации Минздрава России от 25.01.2021.

5 К 13.03.2020, когда партнерские роды временно запретили в столичных медицинских учреждениях в связи с COVID-2019, 14.08.2020-возобновили.
} 
Пять роддомов, куда сейчас пускают доул по ОМС: 24, 20, 1, 70, Зеленоградский ПЦ. В 8-м роддоме заведующий сказал, что ему невыгодно пускать по ОМС. <...> Но акушерский подход отличен от доульского. Очень. И с доулой по ОМС 20-25 тысяч, а с акушеркой хоть индивидуальной, хоть от ЦТА - сразу под 200. Поскольку без контракта с роддомом не дадут. (Доула, юрист, трое детей, 15.01.2020)

Привлекая помощницу для физической, информационной и эмоциональной поддержки в родах по ОМС, женщина теоретически может не заключать отдельный платный контракт с медицинским учреждением при отсутствии необходимой денежной суммы - на такое будущее рассчитывает доульское сообщество. Данные перспективы свидетельствуют о большом потенциале развития доульского сопровождения на массовом бюджетном рынке родов по ОМС при условии законодательного закрепления возможности выбора женщиной немедицинской и несемейной заботы на территории роддома. Однако медицинская реальность такова, что сегодня (до пандемии и после 14 августа 2020 г.) доулы ходят в остальные (неназванные информанткой) учреждения в рамках платных контрактов и стараются выбирать только те места и тех медиков, с которыми у них есть неформальные договоренности или хотя бы позитивный опыт взаимодействия.

[Много ли роддомов, которые принимают доул? Есть те, которые отказываются до сих пор?] Так в основном все отказываются. Просто сейчас появились контрактные роды. Контрактные роды некоторую свободу все-таки женщине предоставляют. Потому что отдельная палата - она может привести с собой кого угодно. Когда просто ты приходишь и тебе как бы позволили быть-это один вопрос. А другой вопрос, когда ты некая часть команды, когда здесь у тебя есть хорошее взаимодействие с врачом (он тебе доверяет), с акушерками этого роддома. Ты как бы не совсем чужой человек, на тебя не делают стойку. Это не значит, что доула вмешивается как-то в процесс родов, какие-то указания дает. Но больше доверия, расслабления у всех. И тогда для процесса это лучше, понимаешь? Когда приходишь в чужой роддом и там ты как бы... Ну, как бы тебе: “А кто это вообще? И че она тут? А от нее чего-то ждать. Вдруг она вместо массажа ей что-то плохое про нас наговорит?" Ну, такое напряжение повисает, да? Как бы в чужой монастырь зашли со своим уставом какие-то странные люди - какие-то помощники в родах. И я их вот в принципе понимаю, чисто вот психологически. И моя задача обычно с ними контакт налаживать. Иногда это очень сложно - и с женщиной быть, и с роддомом контакт налаживать. Такая двойная нагрузка получается. Когда уже контакт налажен и все хорошо, ты приходишь и можешь быть просто спокойно с женщиной. Тебе не надо им рассказывать, а какие у клиентки ценности, что бы мы хотели реализовать в родах. Больше сил просто для того, чтобы, ну, быть с женщиной, ее поддерживать, помогать ей. (Доула, психолог, трое детей, 12.02.2018, 17.02.2018)

Однако риск отказа пациентке в заботе доулы по ОМС сохраняется до сих пор, даже в проверенных роддомах (и особенно в период пандемии), несмотря на все попытки расширенного толкования сообществом норм ст. 51 Ф3 № 323 от 22.11.2011 в пользу возможности применения права партнерских родов к доульскому сопровождению женщины. В доульском сообществе по-разному реаги- 
руют и интерпретируют такие отказы. Репрезентации наиболее типовых реакций и частотные интерпретации приведены в цитате и в следующих параграфах.

Есть еще много вот какого-то такого недоверия к этой профессии. Ну, не настолько она еще популяризирована. То есть да, уже больше знают-вот сейчас уже другая история. Но все равно есть еще какие-то устои роддомов. И, значит, у нас есть еще такое, что во многих роддомах Питера до сих пор еще есть общие родильные залы -это вот является проблемой. Да, то есть в этих роддомах даже с мужем можно получить отказ, если нет индивидуального родильного зала. [В Москве такого нет, да?] Мне кажется, нет. $<. .>$ А у нас только с индивидуальными боксами буквально несколько роддомов. [И это платные, разумеется, да?] Нет, они бесплатные, то есть там есть первый роддом, шестнадцатый роддом - там боксированная система, десятый роддом, в Пушкине роддом. И вот, соответственно, в них теоретически можно попасть с партнером по ОМС. Чаще всего желательно, чтобы этот партнер был мужем. Но где-то, даже если ты позвонишь по справочной, скажешь, могу ли я по ОМС прийти рожать там с сестрой, допустим, да? Скажут, да, можешь. Вот. Но у меня дважды были истории, когда да, вроде как можешь. Мы приезжаем, а там, допустим... Первый раз была история - уженщины было полное уже раскрытие, когда мы приехали. И ей сказали: «Нет, никакого сопровождения. Ты уже рожаешь. Зачем тебе нужно сопровождение?" А второй раз женщина с двойней легла на дородовое. Иу нее начались схватки ночью. И пока ее посмотрели, пока ее перевели - у нее тоже уже к моменту перевода в родильный зал, у нее тоже уже было полное раскрытие. И она очень просила у врача, можно ли ей сопровождение. Я сидела внизу, ждала, чтобы меня пропустили. Вот ей сказали тоже, что нет. "Ты уже все, вот у тебя уже ребенок, дети как бы, мы вот сейчас уже рожаем, поэтому никакого сопровождения". Да, меня тоже это возмущает. Но это же как раз те самые права женщин. И сначала мы отстаивали себя словами, что не каждая, кто называет себя доулой, является доулой, да. То есть очень часто, когда это было новое слово, пользовались им домашние акушерки чтобы себя обезопасить и оградить. Что вроде как я не акушерка, я "доула", а при этом принимали домашние роды. Из-за этого пошла вот эта путаница. Да, что доул почему-то стали приписывать к домашним родам, потому что недобросовестные акушерки называли себя этим словом. (Доула, экономист, один ребенок, 17.08.2020)

\section{Производство доульского дискурса в условиях конкуренции агентов заботы: обоснование специальной немедицинской компетенции, артикуляция границ, стандартов и этики}

Собранные полевые тексты доульского самопредъявления и самоидентификации, способы эмной репрезентации функционала немедицинских помощниц могут варьироваться в зависимости от авторской интенции и контекста: публичное или закрытое мероприятие, очное или дистанционное обучение, бытовое общение или переговоры с клиентками, процесс оказания услуг в домашнем или больничном пространстве, (не)формальные взаимодействия с медиками. Прагматический анализ текстов, используемый в моем исследовании, предполагает, согласно принятой в теории коммуникации традиции, рассмотрение их как высказываний, имеющих адресанта и адресата, которых соединяет определенная коммуникативная интенция [Бахтин, 1979]. 
В письменных и цифровых текстах, направленных широкому кругу адресатов, доулы часто представляются как специалисты, оказывающие «психологическую, информационную и физическую поддержку" в родах, а также "защиту интересов женщин", которые образно обозначаются как "четыре кита", определяющие суть и внешнюю миссию помогающей работы ${ }^{6}$. Однако индивидуальные интерпретации данных основополагающих элементов заботы (особенно «защита интересов женщины") могут серьезно разниться даже у доул, обучавшихся по одной программе, в силу различий их образовательного бэкграунда, личного опыта родов и навыков немедицинских сопровождений.

[Я как-то посмотрела список доул и увидела, что некоторые-с психологическим, некоторые - с юридическим образованием. Я так поняла, они выступают как защитницы. Они самопрезентуют себя женщинам как люди, которые будут их защищать в случае избыточного вмешательства, еще как-то. Тебе приходилось так работать?] Я с этого начинала. Мы когда-то с этого начинали тоже, когда в одном центре я работала. Этот центр делал презентацию психолога на родах, доулы или того, кто с женщиной будет, что в случае чего этот человек будет защищать интересы женщины. Я считаю, что это уже как бы устаревший взгляд на доул. Знаешь, почему? Потому что, если готовиться к войне... И тоже в подготовке к родам была такая тенденция: там, где было торжество информации, там же было, что мы уже знаем о своих правах, придем подготовленные, ничего подписывать не будем, будем требовать того, будем требовать сего, сошлемся на закон - ну как бы такое. Не работает это. Сейчас объясню, почему. Потому что, если только возникает конфликт в родах и вообще какая-то история борьбы, нет ощущения безопасности. Течение родов может нарушиться из-за этого. Потому что, если ты пришел на войну, какие роды? Если ты пришел воевать за свои права, как ты можешь отпустить себя, расслабиться и довериться? Поэтому, мне кажется, доверие гораздо ценнее. Поэтому лично я как доула люблю работать с местами, которым я доверяю, с людьми, которым я доверяю. То есть там, где априори не нужно будет женщину ни от чего защищать. Тогда есть чем другим заняться. Понимаешь, если ты на войне, то ты на войне. Ты сидишь с условным маузером и отстреливаешься. Но ты тогда не с женщиной. Ты не можешь быть с ней в точке боли. Там ты беззащитен, там ты так же, как она, абсолютно уязвим, беззащитен. (Доула, психолог, трое детей, 12.02.2018, 17.02.2018)

В коммуникациях, нацеленных на непосредственные продажи услуг клиенткам, отдельно предлагается "непрерывность" сопровождения до и после родов за дополнительную почасовую оплату (по аналогии с акушерской и медицинской помощью) и подчеркивается независимость от роддома. Однако де-юре в столичных роддомах можно встретить штатных психологов, работающих по трудовому договору в составе родильной команды, в том числе как доулы, что, по мнению авторитетных доул (стейкхолдеров образовательного активизма), противоречит самой концепции доульства, предполагающей обязательность автономного

\footnotetext{
6 Доказательная медицина о доулах: Кто это и почему их работа эффективна? // Doula Link. 2018. 18 aпреля. URL: https://doula.link/2018/04/18/dokazatelnaya-meditsina-o-doulah-kto-eto/ (дата обращения: 24.05.2021); Кто такая доула? // Ассоциация Профессиональных Доул. URL: https://doularussia.ru/faq/whois (дата обращения: 24.05.2021).
} 
(от учреждения) положения помощницы, которая находится именно на стороне женщины.

Потому что среди доул есть клинические психологи, которые трудоустроены в родильных домах. Они продолжают сопровождать. [А это в Москве или в Питере? Я слышала, что в Питере такая практика трудоустройства. В Москве разве есть?] У нас есть несколько клинических психологов, которые работают в роддомах. Да, они не как доулы работают. Они работают, как психологи. Но при этом они могут сопровождать тоже какие-то там свои роды. [Отдельно как бы от жизни роддома?] Нет, не отдельно, это тоже какой-то там контракт должен быть, насколько мне известно. (Доула, психолог, врач, пять детей, 05.04.2020)

При взаимодействии с медиками и в ходе обучения беременных женщин доулы акцентируют необязательность медицинского образования, но желательность позитивного опыта собственных родов. Между тем интервьюирование показало, что доулы могут иметь и высшее, и среднее специальное медицинское образование, и практический опыт работы в медицине, которыми они могут обнадеживать клиенток (например, представляясь как монитрис) или применять частично в своей доульской практике. Однако необходимость гармоничного взаимодействия с медиками принуждает их строго соответствовать этическому кодексу и стандартам практики ${ }^{7}$, подчеркивать принципиальное отсутствие медицинской оценки среди доульских функций, чтобы не пересекаться с компетенцией врачей и не создавать открытых конфликтов. Активное использование дисфемизмов ("сиделка") и переводов термина доула с греческого на русский (“рабыня») несет аналогичную цель и позволяет доулам маркировать свое отличие, чтобы "разотождествиться" с функционалом независимых индивидуальных акушерок со средним медицинским образованием и "склонного к выгоранию" медицинского персонала роддома, не имеющего времени и "ресурса" на индивидуальную заботу на "конвейере/потоке».

Это слово зарубежное, на самом деле не очень важно, как мы назовем эту работу, как мы будем называть такую поддержку. Это помощница в родах или... Перинатальный психолог уже имеет какие-то свои стандарты, но очень часто доулы имеют психологическое образование. Очень часто доулы приходят в эту профессию после рождения собственных детей. Поэтому на самом деле, когда я думаю про доульскую помощь, скорее всего, для меня очень органично такое название, как помощница в родах. Знаете, такой образ у меня всегда встает православной иконы, икона Богородицы, которая называется "Помощница в родах". Мне кажется, это очень близко к пониманию самой работы, смыслового содержания этой работы. На мой взгляд, доульская работа совершенно бесценна, она очень нужна и необходима для женщин. Очень здорово, что у нас сейчас появилось такое пространство, возможность, когда доула может прийти в родильный дом и оказать женщине поддержку. Но если говорить немножко образно,

\footnotetext{
7 См. Этический кодекс организаций - членов Европейской сети доул // Европейская Сеть Доул. 2015. URL: https:// doula.link/code/ (дата обращения: 24.05.2021); Этический Кодекс родовой доулы // Ассоциация Профессиональных Доул. URL: https://doularussia.ru/ethic (дата обращения: 24.05.2021); Сфера деятельности и компетенция родовой доулы // Ассоциация Профессиональных Доул. URL: https://doularussia.ru/sphere (дата обращения: 24.05.2021).
} 
знаете, для меня доула - это такая женщина, прежде всего женщина, чаще всего это рожавшая женщина. Наверное, будем делить, чтобы знать, что есть доулы нерожавшие, не имеющие опыт собственной беременности и родов. Потому что все-таки, когда доула готовит женщину к родам, когда она рассказывает о беременности, чаще всего вербально/невербально передается личный опыт и личное переживание. Хотя я допущу, что есть какие-то зрелые, мудрые женщины, которые приходят к доульской практике, не имея собственных детей. В общем, все зависит от душевных сил и психологического таланта, душевного таланта определенного. Поэтому доула - это, прежде всего, знаете, это женщина, которая генерирует некое поле, психологическое пространство, в котором комфортно рожать. Это человек, который прежде всего, находясь сама в правильном состоянии, способствует формированию такого психологического поля, где женщине хорошо. (Акушерка, руководитель, трое детей, запись вебинаров 19.03.2018, 10.04.2018)

Руководители частных медицинских (акушерских) центров четко разграничивают компетенции акушерок и доул, подчеркивая немедицинскую специфику новой занятости, чтобы не только помочь клиенткам выбрать из специалистов центра подходящего помощника в роды и обосновать зависимость ценового вознаграждения от функционала и ответственности, но также защитить ценность и значимость своих образовательных программ и стандартов.

Очень частая история, когда будущие акушерки, студентки акушерского дела, занимаются доульской практикой. Очень распространенная история. Хочу сразу сказать, что, если доула, практикующая доула, является студенткой акушерского училища это не есть какое-то преимущество. Это только говорит о том, что доула хочет иметь немножечко другие компетенции и чуть-чуть по-другому работать. Но для доулы как для специалиста это не прибавляет ничего и не убавляет. Доула - это абсолютно самостоятельная профессия. (Акушерка, руководитель, трое детей, запись вебинаров 19.03.2018, 10.04.2018)

Вариативные переводы терминов, подчеркнутое отношение к границам компетенции, а также к личному позитивному опыту родов, наличию душевного таланта сопереживания и материнской эмпатии, психологическому пространству человечности и доверия [Arney, 1982; Arney, Neill, 2008] - все это позволяет доулам обосновать свою немедицинскую и персонализованную нишу эмоциональной и телесной заботы о женщине на территории медицинского учреждения.

Потому что медицинская система, она за своей маской стерильной. Они надели маски и халаты. И они не в поле сопереживаний человека. Они могут глубинно сопереживать то, что они выбрали эту профессию. Их миссия - помогать, но это где-то такая большая миссия, а не с каждым конкретным человеком порой. Потому что выгорание очень эмоциональное высокое в этой среде. Колоссальное! То есть медики выгорают очень быстро. Встречаясь постоянно с переживанием боли, в конце концов они выгорают и эмоционально уже ничего не чувствуют. А это очень пациенткой сразу ощущается: чувствует что-то человек, который рядом с ней на родах. А доулы пришли 
как бы и пришла некоторая человечность туда. То есть женщина может брать с собой человека, кто будет сопереживать ее боли. Поэтому много на самом деле не возьмешь людей. Потому что это, с одной стороны, профессия, а с другой-трудно назвать это профессией. На потоке невозможно ее выполнить. Если ты возьмешь больше, чем ты можешь вынести, тут же выгоришь. Там тоже также очень сильная степень выгорания, и тоже перестанешь сопереживать. Поэтому для того, чтобы быть доулой, нужно сохранять способность чувствовать, сохранять собственный контакт со своими чувствами, с болью. И очень четко понимать, что ты не можешь больше. Физически сколько может твое тело пропустить? Сколько может твоя психика пропустить вот этой боли? (Доула, психолог, трое детей, 12.02.2018, 17.02.2018)

Акцентированное внимание на этическом кодексе доул, "стандартах практики", "немедицинской заботе", "границах компетенции", "индивидуальном сопровождении", "опасности профессионального выгорания", а также на "основных потребностях женщин", Оденовском "принципе три $T_{\text {" }}^{8}$, "праве информированного согласия и отказа от медицинских вмешательств", "безоценочности" позволяет доулам пересобирать и коммодифицировать популярные и востребованные концепты, рецепированные из психологического, юридического, академического, этнографического и иных дискурсов.

В некоторых ситуациях, засвидетельствованных в ходе обучения и взаимодействия с клиентками, доулы, вооружившись концептом "безоценочности", отстраняются от подходов, стигматизированных медиа, конкретной клиенткой или контекстом (например, от следования ортодоксальному варианту парадигмы "естественных родов", не признающему рутинное применение синтетического окситоцина, эпидуральной анестезии, кесарева сечения, эпизиотомии), и поддерживают любые решения женщин, подчеркивая свою работу "у головы клиентки" (в оппозиции к работе акушерки).

Ну как мы безоценочно ведем себя в родах? То есть, если женщина там хочет сделать эпидуральную анестезию. А доула, например (ну, мы же все равно люди, да, в душе), например, доула считает, что эпидуральная анестезия - вот себе она бы никогда не сделала, например. И в то же время отговаривать женщину она же не будет и говорить: «Ну, ты что? Эпидуральная анестезия - это же такие последствия могут быть там. Лучше ты не делай. Давай я сейчас тебе сделаю массажик. Там, пойдем в душ. Я знаю, как тебе помочь". Вот это, конечно, категорически нет. А если женщина говорит: “Нет, все. Я устала. Я хочу эпидуральную анестезию. Очень сильно. Я помню, мы с тобой договаривались, что я ставить не буду. Но я все равно хочу". То есть, ну, мы идем за женщиной, да. Ее не отговариваем ни от чего и ни на что не уговариваем. Вот в этом тоже безоценочность. (Доула, переводчик, трое детей, 10.04.2020)

Подобный политкорректный этический стандарт и тактика общения с клиентками, основанные на "безоценочности" и толерантности, позволяют доулам пластично и гибко отвечать на разнообразие женских запросов, что приводит, как

\footnotetext{
8 Согласно концепции Мишеля Одена принцип «три Т» предполагает соблюдение трех условий в родах - тихо, тепло, темно.
} 
минимум, к расширению круга беременных клиенток, имеющих медикализированные и иные отличные от радикальных направлений деторождения представления о родах. Однако "толерантная" риторика доул вызывает у конкурирующих поставщиков перинатальных услуг, легально вписанных в медицинский ландшафт, критику при интерпретации двух качеств, которым должна руководствоваться доула,- «безоценочность" и отсутствие медицинской квалификации.

Очень часто в профессиональных сообществах звучит такая тема: доула - безоценочная, акушерка - оценочная. У меня есть к этому очень много противоречий, потому что, на мой взгляд, профессиональная практика прежде всего строится на оценочности. Невозможно помочь, если ты до этого не оценил те процессы и явления, в которых ты участвуешь, потому что, только оценив их, можно принять правильное решение и понять, как помочь. Нельзя оценивать какие-то личные компоненты, нельзя оценивать лично женщину. Надо оценивать процессы и явления событий, в которых вы участвуете,- совершенно необходимо, иначе сложно будет понять, что вообще происходит. Поэтому безоценочность здесь не очень-то правильна. Возникла эта тема безоценочности именно потому, что... Самая распространенная история, когда доула присутствует на родах и женщина, например, захотела эпидуральную анестезию. Доула не оценивает, доула принимает любое решение женщины. А акушерка традиционного направления, скорее всего, внутренне может роптать. Особенно если женщина хорошо рожает, все замечательно - у нее шейка открывается, роды замечательно идут. Но в какой-то момент женщина сказала: "Я хочу эпидуральную анестезию". В этот момент акушерка традиционного направления внутренне может не согласиться с этим, акушерка может подсказать женщине, как же можно все-таки попробовать пройти естественно этот путь. Но, если женщина будет настаивать, никакая акушерка не имеет право не согласиться и противоречить. Хотя я допускаю, есть такие акушерки, которые выполняют материнскую функцию. Они могут начать воспитывать: "Что это такое вы говорите?" И показывать всем своим видом, что они не соглашаются, хотя этого делать нельзя. Потому что это как раз проявление непрофессионализма. Постановка вопроса здесь неправильная, потому что доула - это не медик. Доула вообще никак не может включаться и оценивать любые медицинские манипуляции. Поэтому нужна эпидуральная анестезия, хочет ее женщина, не хочет, нужно ей какое-либо лекарство или какая-то манипуляция и прочие медицинские вопросы - это вообще не про деятельность доулы. Поэтому по-хорошему в эту сторону доула вообще не должна и не имеет права смотреть, потому что у нее нет специального образования. Поэтому доула работает, прежде всего, с психологическим состоянием женщины, создавая это состояние спокойствия и невозмутимости для женщины в родах. (Акушерка, руководитель, трое детей, запись вебинаров 19.03.2018, 10.04.2018)

По мнению самих доул, польза от их "безоценочной" и "немедицинской" деятельности "сиделок" позволяет женщинам "повысить удовлетворенность" даже бюджетными родами в пространстве, которым она не может управлять, поскольку существует кохрейновское исследование о значительной пользе заботливого участия доул в родоразрешении, способствующее повышению удовлетворенности родами, снижению длительности родов и частоты применения окситоцина, кеса- 
рева сечения 9 . Чтобы разотождествиться и косвенно управлять "оценивающими" конкурентами с медицинским образованием - врачами и акушерками, в ходе обучения и взаимодействия с клиентками доулы широко опираются на доказательную медицину и рекомендации ВОЗ, как следует из собранных полевых материалов. Данное явление свидетельствует, на мой взгляд, о том, что активное использование метаданных кохрейновских обзоров и гайдлайнов ВОЗ подразумевает возможность косвенного информационного управления и изменения ситуации в родах (при условии согласования роженицей медицинских вмешательств (или их отказа от них) с врачами и акушерками, которые несут правовую ответственность за принимаемые решения).

Довольно часто доулы считают актуальным, модным и даже этичным участвовать в популяризации иностранных феминистских и доульских движений, что приводит не только к появлению соответствующей терминологии в текстах, но также к ее различным интерпретациям (благодаря доульскому коучингу и присутствию на родах) и мобилизации по-разному понимаемой, например, женской агентности.

Таким образом, анализ собранных полевых текстов и наблюдений свидетельствует о том, что доулы артикулируют компетенцию и границы деятельности с разной прагматикой в зависимости от разных фреймов. Форматы мероприятий, письменный, устный или дистанционный характер коммуникации, авторские интенции высказываний меняют риторический жанр и способствуют определенной вариативности текстов [Бахтин, 1979; Щепанская, 2010]. Из перспективы клиента множественные ролевые идентичности специалистов, предъявляющих себя в качестве доул, (равно как и сами практики) конструируются и интерпретируются участниками коммуникации (в зависимости от контекста) как через оппозицию к бюджетной системе родовспоможения с ее медикализированным, патерналистским и конвейерным подходом к родам, женщине и младенцу, так и через критику стигматизированных практик "духовного", "естественного" и домашнего акушерства. Современные доулы эмансипируются от предыдущего наследия альтернативных и независимых перинатальных специалистов, скомпрометированного медийным, судебным, медицинским дискурсом.

Участники доульской сети активно продвигают многообразный спектр перинатальных услуг, используя декодирование и ребрендинг стигматизированных терминов, выработку новой аксиоматики и специализированного языка, позволяющего претендовать на автономное экспертное знание.

\section{Образовательный и просвещенческий активизм, нелегальность практики, негативная реципрокность}

На рубеже 2014/2015 гг. пассионарные (активные) и многоязычные перинатальные специалисты, имеющие широкую географию своего проживания, несколько высших образований и разносторонний опыт деятельности, организовали Институт перинатальной поддержки (doula.link) и монетизировали программы

\footnotetext{
9 Как правило, доулы объясняют полезность немедицинской непрерывной поддержки (и подразумевают под этим доульское участие) через апелляцию к мнению ВОЗ и кокрейновским обзорам. См. Шрайбман Л. Исследования о поддержке в родах // Doula Link. 2018. 27 февраля. URL: https://doula.link/2018/02/27/issledovaniya-o-podderzhkev-rodah/ (дата обращения: 24.05.2021).
} 
обучения "профессиональных" и "послеродовых" доул, по итогам прохождения которых выдаются сертификаты и организуется волонтерская практика для приобретения выпускницами первичных навыков ${ }^{10}$. Если в 2011 г., когда состоялся первый российский тренинг подготовки помощниц в родах, его длительность составила "первые и последние выходные мая" ${ }^{11}$, то к началу 2021 г. период обучения увеличился до четырех месяцев, необходимых для интенсивной программы освоения специальных знаний, стандартов и этики.

Поскольку правительственные регуляторы и законодатель не признают существование доульской занятости, отсутствуют государственные требования к деятельности и сертификации данных агентов немедицинской заботы, то на нерегулируемом образовательном рынке присутствует конкуренция среди образовательных стейкхолдеров ${ }^{12}$, позволяющая ускоренно и интенсивно распространять представления и этические ценности доульской практики среди будущих доул и матерей. Часто "гарантийное место" государственного признания занимают ссылки на международные ассоциации доул (например, членство в European Doula Network) или образовательные лицензии, наличие которых пока не обязательно для осуществления данной образовательной деятельности ${ }^{13}$.

Несколько позднее, в 2017 г., активно практикующие доулы на паритетных основаниях объединились в общественную организацию-Ассоциацию профессиональных доул (АПД) - для защиты прав беременных и матерей, для взаимного обучения, обмена навыками и практиками, а также для лоббирования коллективных и скорее уже корпоративных интересов - получения доулами законного статуса и права деятельности на территории медицинского учреждения, внесения новой занятости в общероссийский классификатор профессий ${ }^{14}$.

[Сколько работает доул в Москве? Примерно?] Активно, думаю, от 45 до 60. Разово, изредка - больше. Это из доул АПД. А кто там невнятные духовные акушерки, почему-то зовущие себя доулами, - неведомо. До нас порой доходят слухи и жалобы из роддомов, а мы и не знаем, что это был за человек и почему назвал себя доулой. (Доула, юрист, трое детей, 15.01.2020)

Не все организации, созданные доулами в форме некоммерческих, претендуют на саморегулирование своих членов, но в большинстве случаев они пытаются стандартизировать доульскую практику посредством аффилиации или слияния

\footnotetext{
${ }^{10}$ См. Профессиональная доула. Программа сертификации // Doula Link. 2021. URL: https://portal.doula.link/reg/for/ pro/ (дата обращения: 24.05.2021); Правила участия в волонтерской программе // Doula Link. URL: https://doula. link/volunteering_terms/ (дата обращения: 24.05.2021).

${ }^{11}$ См. Стрельцова Д. Юбилей // Facebook. 2021. 2 мая. URL: https://www.facebook.com/100023498553543/posts/ 949572349169375/?d=n (дата обращения: 24.05.2021).

${ }^{12}$ См. Как стать доулой? / Ассоциация Профессиональных Доул. URL: https://doularussia.ru/howto (дата обращения: 24.05.2021); Профессиональная доула. Программа сертификации // Doula Link. 2021. URL: https://portal.doula. link/reg/for/pro/ (дата обращения: 24.05.2021); Школа доул. Программа обучения // Akusherstvo Club. 2021. URL: https://akusherstvo.club/na-doulu (дата обращения: 24.05.2021); Курс "Я доула" // Акушерка.Про. 2021. URL: https:// akusherka.pro/obuchenie/doula-obuchenie/ (дата обращения: 24.05.2021).

${ }^{13}$ См. Акушерство Про. URL: http://akusherstvo.pro/contacts (дата обращения: 24.05.2021).

${ }^{14}$ См. Об АПД // Ассоциация Профессиональных Доул. URL: https://doularussia.ru/about (дата обращения: 24.05.2021).
} 
с образовательными центрами. Члены АПД также регулярно обсуждают и унифицируют доульские подходы, обмениваются инсайдерской информацией о лучших/ худших акушер-гинекологах, локальных протоколах, рутинной практике городских роддомов. В это же время (по аналогии с проектами и конференциями идеологов "естественных" родов) получила распространение регулярная коллективная практика одновременного самопродвижения и самопродажи через организацию и проведение доульскими некоммерческими организациями офлайновых и онлайновых конференций, платных или рекламных мероприятий по обмену опытом и знаниями, а также через реализацию волонтерских проектов в дружественных роддомах ${ }^{15}$.

В реальности, находящейся за пределами рекламных, образовательных, активистских и коллективных репрезентаций "несомненной полезности" заботы в родах, большая часть рядовых доул, особенно в регионах, согласно данным интервьюирования, нечасто оказывает помощь женщинам в родах непосредственно в роддоме, преимущественно - в платных родах или гораздо реже в родах по ОМС (в качестве квазиродственниц или волонтеров на территории лояльных роддомов). Очень часто доулы рассказывают о запретах немедицинского сопровождения женщин, особенно во время пандемии.

Сопровождения запрещены. Это карантинная мера. И они запрещены по всем роддомам Москвы. <...> Единственный роддом в Красногорске остался, где разрешены сопровождения. И то я, честно говоря, не знаю, насколько там это все. [А запрещены и папам тоже, да?] Да. Всем. Партнерские роды вообще. Ну, это карантинная мера. Это форс-мажорные обстоятельства. Да, то есть мы должны понимать, что это не потому, что врачам захотелось перестать пускать партнеров на роды. Это именно для того, чтобы избежать распространения инфекции. Как бы понятно, что к этому есть вопросы. <...> [А контрактные? А если это контрактные роды? Если они оплачены именно специально под акушерку, под доулу. Что делать?] Ну, акушерки, кто трудоустроен официально, они продолжают брать контракты и вести сопровождение. Если это индивидуальная акушерка. Понимаете, доулы вне закона. Нет такой профессии доула. Нет женщины, которая работает доулой официально в роддоме. Если бы это было возможно, то, наверное, не было бы никаких проблем. (Доула, психолог, врач, пять детей, 05.04.2020)

В ходе коллективного обсуждения таких сюжетов в сети или на конференциях в доульском сообществе принято артикулировать проблемы несправедливых ограничений прав беременных и рожающих женщин при толковании 323-Ф3 ${ }^{16}$ на местах, бессмысленности антиковидных и карантинных ограничений, принятых регулятором [Кукса, 2020а], а также недоверия медиков самому институту доульства из-за локальных конфликтных кейсов несоблюдения границ компетенции "женщиной, представившейся доулой". Предлагаются решения проблемных вопросов в активистском ключе: призывы напрямую прописать в законе возможность именно доульского (не только партнерского) сопровождения в бюджетных родах

\footnotetext{
${ }^{15}$ См. Правила участия в волонтерской программе // Doula Link. URL: https://doula.link/volunteering_terms/ (дата обращения: 24.05.2021); Доулы-волонтеры // Акушерство Про. URL: http://akusherstvo.pro/douly-volontery (дата обращения: 24.05.2021).

${ }^{16}$ Федеральный закон от 21.11.2011 № 323-Ф3 “Об основах охраны здоровья граждан в РФ».
} 
и пускать в роддом только вступивших в ассоциацию сертифицированных доул, соблюдающих этический кодекс и стандарты практики.

С другой стороны, у начинающих доул существует также проблема поиска клиенток, в отличие от передовых и активных членов сообщества, организовавших (и коммодифицировавших) образовательную среду для передачи навыков и опыта, наработанный социальный капитал и, следовательно, относительно стабильный доход. По данным интервьюирования, рядовые участницы, недавние выпускницы, осуществляют доульскую поддержку в роддоме окказионально: сначала близкому окружению, потом выпускницам собственных курсов по подготовке к родам и читательницам своих блогов. Начинающие доулы вовлекаются в новую прекарную занятость и рассчитывают на дополнительный источник дохода, несмотря на то, что большая часть женщин имеет как минимум одно высшее образование и опыт работы, а также воспитывает и содержит чаще всего несколько (необязательно) малолетних или подросших детей, постоянную заботу о которых, как минимум в период декретного отпуска, ей некому делегировать (согласно результатам полевого интервьюирования). Данные семейные ограничения не позволяют матерям участвовать в предыдущей деятельности (обеспечивающей ее до родов) с полной силой, отдачей и вознаграждением. Многодетным женщинам также тяжело совмещать воспитание маленьких детей с доульскими сопровождениями.

Я не озвучиваю, потому что, ну, у меня такая ситуация, у меня муж в Америке работает сейчас. И я одна с тремя детьми. У меня в принципе мало возможностей сейчас вот там ходить на роды часто. Я даже не афиширую сейчас, что вообще какие-то услуги делаю, что иногда работаю периодически. Но я даже не озвучиваю. Вот эти вот роды онлайн или не онлайн. Если там это какие-то другие могут делать, но для меня роды сейчас... Фактор, что мне очень сложно детей куда-то деть. [Я понимаю.] Поэтому я не рекламируюсь. Может быть, если бы я делала побольше рекламы и говорила: "Да, я могу", было бы. Поэтому я, наверное, не показатель. Наш город, наверное, тоже не показатель. Потому что другие девочки тоже этого, кстати, не пишут нигде, хотя могли бы, да. Не знаю, почему они не пишут. Может быть, если бы мы все это предлагали, женщины бы соглашались. [Спасибо за честность, откровенность. Мне уже так отвечала моя подружка из Беларуси, что просто невыгодно ей ходить на роды с маленьким ребенком. Ей проще массажной доулой быть. Вот она просто так сказала.] Вы знаете, не в плане выгоды, я скажу вам еще честнее. У меня муж хорошо зарабатывает. Он в Америке работает. И мне вообще нет необходимости делать это за деньги. Я просто это делаю пока так, потому что мне нравится - в удовольствие, да. И просто мне это очень нравится. Но делать это бесплатно совсем тоже как бы неправильно, я считаю. Но это ресурса много забирает. Я и так с детьми, знаете, с трудом. Вот. Поэтому, ну, вот так. Наверное, если бы у меня был вопрос денег, я бы активнее все это делала. И думала - выгодно, не выгодно. (Доула, переводчик, трое детей, 10.04.2020)

Проблемы поиска клиенток, недостаточной самооценки собственного труда, неоплаты и срыва предварительных договоренностей или контрактов (квалифицированная мною как негативная реципрокность), ожидания регулярного дохода и возмездности от немедицинской заботы в родах открыто обсуждаются на со- 
вместных конференциях, периодических посиделках и платных курсах, в сетевом общении, организуемых ключевыми членами сообщества. Тема различий между осознанным волонтерством и вмененной "благотворительностью" во взаимоотношениях с клиентками получает свое развитие в доульском фольклоре ("утром деньги, вечером стулья", когда доула предполагает, что в будущем консультирует женщину только после предоплаты; “меня зовут Нина, и я люблю женщин за деньги"). С другой стороны, редкость доульских сопровождений объясняется в среде также как конкурентное преимущество: "низкий уровень выгорания", несопоставимый с медицинским, который позволяет доуле быть включенной в заботу о конкретной женщине, не распыляясь.

Однако поскольку существуют прекарные риски, связанные с нерегулярностью запросов и срывами со стороны клиенток или отказом сотрудниками в сопровождении прямо при пересечении порога роддома, доулы предпочитают вовлекаться в широкий спектр перинатальных и консультационных услуг помощи будущим родителям, включая коучинг по подготовке к родам, грудному вскармливанию, уходу за матерью и младенцем после родов. В том числе поэтому сертифицированные доулы активно реципируют экзотические фольклорные тексты и этнографические практики для постнатального периода - индигенные (indigenous) практики традиционного ухода и послеродового восстановления - например, мексиканское пеленание ребозо или баня темаскале [Кукса, 2020b]. Кроме диверсификации деятельности в перинатальной сфере, доулы увязывают новую занятость с базовой/первоначальной специальностью, совмещая, например, с юридическим и психологическим консультированием, а также используют социальные сети и дистанционные способы коммуникации для проведения курсов и консультаций.

Доулы репрезентуют свою профессиональную идентичность, обращаясь также к близкородственным перинатальным ярлыкам/маркерам, определяющим их функционал. Наиболее распространены самопредъявления по факту наличия диплома или сертификата - перинатальный, телесноориентированный или клинический психолог, специалист по грудному вскармливанию, пеленальщица, расстановщица, организатор курсов/клубов и ведущая курсов, инструктор по йоге, слингоношению, питанию, сну, танцам, гипнозу. Но также встречаются имеющие редкое распространение наименования, объединяющие, по представлению специалиста, комплексно доульскую идентичность с иными базовыми профессиями и занятостями - монитрис, юридоула, ментор, арт-терапевт, инструктор по капсулированию плаценты. Некоторые наименования еще не прижились в силу свежей рецепции или уже имеют печальную правоприменительную “судьбу» ${ }^{17}$.

\section{Заключение}

Коллективные и индивидуальные действия участников доульских сетей, связанные с активным низовым продвижением и лоббированием законодательного признания доул в качестве заботящихся о роженице помощниц с немедицинской

\footnotetext{
${ }^{17}$ Среди перинатальных специалистов обсуждаются юридические риски продажи некоторых видов практик, например, капсулирование плаценты может быть квалифицировано согласно УК РФ как незаконная деятельность, связанная с изготовлением биологически активных добавок (лекарств) без лицензии и без соответствия установленным требованиям.
} 
компетенцией, специальными навыками и этическими границами, не получают одобрения государства и сохраняют маргинальное и невидимое для бюрократической системы положение.

Ирония заключается в том, что растущее число обученных и сертифицированных доул (в том числе через своих беременных клиенток) давит на местные родовспомогательные учреждения, а новички готовы волонтерствовать без денежного вознаграждения, чтобы апробировать полученные знания на деле, понять условия и расположенность к подобной занятости. Поэтому парадоксальным образом доульские инициативы остаются востребованными женщинами и одобряются все большим числом медицинских учреждений - даже в массовом сегменте бюджетных родов по ОМС - в формате квазисемейного или волонтерского сопровождения родов.

Проблемы негативной реципрокности и негарантированной, нестабильной женской прекарной самозанятости, совмещения постоянной безвозмездной заботы о собственных детях образованных матерей с нерегулярным возмездным уходом за беременными и родившими клиентками, а также попытки коммодификации и синкретизма материнского и профессионального опыта сопровождают и усиливают инициированные доульской сетью процессы продвижения и популяризации "немедицинской эмоциональной и физической помощи" в родах на территории медицинского учреждения.

Практики "непрерывного", "немедицинского", "информационного", "физического", "эмоционального" сопровождения женщин "профессиональной" доулой де-факто способствуют изменению (право)субъектности роженицы в роддоме и появлению реальной возможности для взаимодействия с монопольной системой родовспоможения в интересах матери и младенца в рамках действующих протоколов и правил. Хотя собранные в ходе исследования интервью свидетельствуют также о том, что реализация индивидуального выбора и вариативность телесных практик нужны не всем беременным женщинам, а только тем, у кого артикулирован запрос на агентность и есть определенное образование, опыт и ценности. В любом случае доульский коучинг и информирование позволяют женщинам становиться обученными пользователями закрытой системы родовспоможения.

Участники доульской сети активно используют декодирование и ребрендинг стигматизированных терминов, выработку новой аксиоматики и специализированного языка, позволяющего претендовать на автономное и исключительное экспертное знание. Подчеркнутая артикуляция границ компетенции, стандартов практики и этики позволяет доулам обосновать свою немедицинскую и персонализированную нишу эмоциональной и телесной заботы о женщине на территории медицинского учреждения.

Фактическое проникновение немедицинских практик эмоциональной и физической заботы в роддом, образовательный и цифровой активизм доульской сети, приводящий как к росту количества сертифицированных доул, так и к производству специальной компетенции, навыков, стандартов, этики и языка, способствуют ускоренному изменению всего медицинского ландшафта, биомедицинских знаний и дискурса в сторону дальнейшей гуманизации родовспоможения - пациентоориентированной коммуникации, информированного согласования медицинских 
вмешательств, частичной демедикализации, учета данных доказательной медицины в новых протоколах и рутинных практиках, расширения агентности рожениц при выборе места, участников, протокола и способа родов.

\section{Список литературы (References)}

Абрамов Р.Н. Логики профессионализма Э. Фрейдсона: текстологический анализ // Профессионалы в эпоху реформ: динамика идеологии, статуса и ценностей. М.: Институт социологии РАН, 2013. С. 21-37.

Abramov R. N. (2013) The Logics of E. Freidson's Professionalism: Textological Analysis. In: Professionals in the Era of Reforms: Dynamics of Ideology, Status and Values. Moscow: Institute of Sociology RAS. P. 21-37. (In Russ.)

Абрамов Р.Н. Социология профессий и занятий: очерки истории и ключевые концепции дисциплинарной области. М.: ООО Вариант, 2016. 452 с.

Abramov R. N. (2016) Sociology of Professions and Occupations: Essays on History and Key Concepts of the Disciplinary Field. Moscow: Variant. (In Russ.)

Абрамов Р.Н. Профессиональная этика в контексте социологии профессий: обзор зарубежных концепций // Социологические исследования. 2018. № 7. С. 87-94. https://www.doi.org/10.31857/S000523100000168-8.

Abramov R. N. (2018) Professional Ethics in the Context of the Sociology of Professions: A Review of Foreign Concepts. Sociological Studies. No. 7. P. 87-94. https://www. doi.org/10.31857/S000523100000168-8. (In Russ.)

Бахтин М.М.Эстетика словесного творчества. М. : Искусство, 1979.

Bakhtin M. M. (1979) Aesthetics of Verbal Creativity. Moscow: Art. (In Russ.)

Бороздина Е. А. "Язык науки и язык любви": легитимация независимой акушерской практики в России // Laboratorium. 2014. T. 6. № 1. С. 30-59.

Borozdina E. A. (2014) Language of Science and Language of Love: The Legitimation of Independent Midwifery Practice in Russia. Laboratorium. Vol. 6. No. 1. P. 30-59. (In Russ.)

Бороздина Е. А. Забота в родовспоможении: выгоды и издержки профессионалов // Журнал исследований социальной политики. 2016. Т. 14. № 4. С. 479-492. Borozdina, E.A. (2016) The Professional Care in Maternity Hospitals: Benefits and Challenges. The Journal of Social Policy Studies. Vol. 14. No. 4. P. 479-492. (In Russ.)

Денисова М. Профессиональная поддержка в родах: роль доул в увеличении агентности матери. Бакалаврская выпускная работа. М. : НИУ ВШЭ, 2019.

Denisova M. (2019) Professional Support in Childbirth: The Role of Doulas in Increasing the Agency of the Mother. Bachelor's Final Work. Moscow: HSE University. (In Russ.)

Кукса Т. Л. Рассказы о родах и родовспоможении в современной городской культуре. Магистерская выпускная работа. М.: РГГУ, 2018.

Kuksa T. (2018) Stories About Childbirth and Obstetric Care in Contemporary Urban Culture. Master's Work. Moscow: Russian State University for the Humanities. (In Russ.) 
Кукса Т.Л. Теоретические подходы к исследованию практик родовспоможения и текстов о родах // Медицинская антропология и биоэтика. 2019. № 1. С. 168 200. http://doi.org/10.33876/2224-9680/2019-1-17/08.

Kuksa T. (2019) Theoretical Approaches to Studies on Practices of Obstetric Care and on Texts About Childbirth. Medical Anthropology and Bioethics. No. 1. P. 168-200. (In Russ.)

Кукса Т.Л. Биополитические решения и правозащитный активизм в период распространения COVID-2019 в России: ограничения субъектности и новые границы взаимозависимости // Медицинская антропология и биоэтика. 2020а. № 1. C. 67-99. http://doi.org/10.33876/2224-9680/2020-1-19/04.

Kuksa T. (2020a) Biopolitical Decisions and Human Rights Activism During the Spread of COVID-19 in Russia: Limitations of Subjectivity and New Boundaries of Interdependence. Medical Anthropology and Bioethics. No. 1. P. 67-99. (In Russ.)

Кукса Т.Л. "Страшилки" для рожениц: конструирование и преодоление страха в родах // Фольклор и антропология города. 2020b. Т. 3. № 1-2. С. 166-187. URL: https://ufajournal.ranepa.ru/upload/iblock/2bf/ufa20_1_10.pdf (дата обращения: 03.07.2021).

Kuksa T. (2020b) “Horror Stories” for Women in Childbirth: Construction and Overcoming of Fear in Childbirth. Urban Folklore \& Anthropology. Vol. 3. No. 1-2. P. 166187. URL: https://ufajournal.ranepa.ru/upload/iblock/2bf/ufa20_1_10.pdf (дата обращения: 03.07.2021). (In Russ.)

Сакс М., Олсоп Дж. Социология профессий: Государство, медицина и рынок в Великобритании // Профессиональные группы интеллигенции / отв. ред. Мансуров В. А. М. : Изд-во ИС РАН, 2003. С. 79-104.

Sacks M., Alsop J. (2003) Sociology of the Professions: State, Medicine and the Market in Great Britain. In: Mansurov V. A. (ed.) Professional Groups of the Intelligentsia. Moscow: Institute of Sociology RAS. P. 79-104. (In Russ.)

Щепанская Т.Б. Сравнительная этнография профессий: повседневные практики и культурные коды (Россия, конец XIX - начало XXI в.). СПб.: Наука, 2010.

Shchepanskaia T.B. (2010) Comparative Ethnography of Professions: Everyday Practices and Cultural Codes (Russia, Late XIX - Early XXI Centuries). St. Petersburg: Nauka. (In Russ.)

Arney W. (1982) Power and Profession of Obstetrics. London: University of Chicago Press.

Arney W. R., Neill J. (2008) The Location of Pain in Childbirth: Natural Childbirth and the Transformation of Obstetrics. Sociology of Health \& IIIness. Vol. 4. No. 1. P. 1-24.

Belousova E. (2012) Waterbirth and Russian-American exchange: From the Iron Curtain to Facebook. Doctoral Dissertation. Houston: Rice University.

Davis-Floyd R.E., Davis E. (1996) Intuition as Authoritative Knowledge in Midwifery and Homebirth. Medical Anthropology Quarterly. Vol. 10. No. 2. P. 237-269. https:// doi.org/10.1525/maq.1996.10.2.02a00080. 
Davis-Floyd R.E., Sargent C. F. (eds.) (1997) Childbirth and Authoritative Knowledge: Cross-cultural Perspectives. Berkeley: University of California Press. https://doi.org/ $10.1525 / 9780520918733$.

Geertz C. J. (1973) The Interpretation of Culture. New York, NY: Basic Books.

Geertz C. J. (1983) Local Knowledge: Further Essays in Interpretive Anthropology. New York: Basic Books.

Jordan B. (1997) Authoritative Knowledge and Its Construction. In: Davis-Floyd R.E., Sargent C. F. (eds.) Childbirth and Authoritative Knowledge: Cross-Cultural Perspectives. Berkeley: University of California Press. P. 55-79. https://doi.org/10.1525/ 9780520918733-003.

Freidson E. (1986) Professional Powers: A Study of the Institutionalization of Formal Knowledge. Chicago, IL: University of Chicago Press.

Freidson E. (1988) Profession of Medicine: A Study of the Sociology of Applied Knowledge. Chicago: The University of Chicago Press.

Freidson E. (2001) Professionalism: The Third Logic. Chicago, IL: University of Chicago Press.

Kleinman A. (1978) Concepts and a Model for the Comparison of Medical Systems as Cultural Systems. Social Science and Medicine. Vol. 12. No. 1. P. 85-93. https:// doi.org/10.1016/0160-7987(78)90014-5.

Saks M. (1994) Professions and the Public Interest. Medical Power, Altruism and Alternative Medicine. London: Routledge.

Saks M. (eds.) (1995) Health Professions and the State in Europe. London: Routledge.

Saks M. (1998) Professionalism and Health Care. In: Field D. and Taylor S. (eds.) Sociological Perspectives on Health, Illness and Health Care. Oxford: Blackwell Science.

Saks M. (2003) Orthodox and Alternative Medicine: Politics, Professionalization and Health Care. London: Continuum.

Saks M. (2010) Analyzing the Professions: The Case for the Neo-Weberian Approach. Comparative Sociology. Vol. 9. No. 6. P. 887-915. https://doi.org/10.1163/ $156913310 \times 522624$.

Saks M. (2012) Defining a Profession: The Role of Knowledge and Expertise. Professions and Professionalism. Vol. 2. No. 1. P. 1-10.

Rouhier-Willoughby J. (2008) Village Values: Negotiating Identity, Gender, and Resistance in Urban Russian Life-Cycle Rituals. Bloomington: Slavica Publishers. 